\title{
PENDAMPINGAN PERKEMBANGAN ANAK BERKEBUTUHAN KHUSUS KATEGORI GIFTED BERDASARKAN POLA ASUH OTORITATIF
}

\author{
Sriyati $^{1} \&$ Hergyana Saras Ningtyas ${ }^{2}$ \\ Sekolah Tinggi Agama Kristen Terpadu Pesat Salatiga ${ }^{1 \& 2}$ \\ sriyatigamba@gmail.com ${ }^{1}$, hergy.ningtyas@ gmail.com²
}

\begin{abstract}
Abstrak
Anak berkebutuhan khusus memiliki kasus yang beragam. Penelitian ini akan fokus membahas perkembangan anak berkebutuhan khusus berdasarkan pola asuh otoritatif. Tujuannya agar orang tua dapat memahami jenis dan faktor penyebab anak berkebutuhan khusus kategori gifted, sehingga dapat memperhatikan pengasuhan terhadap anak secara tepat. Penelitian ini dilakukan pada bulan Oktober 2020 - Juli 2021 Desa Lopait RT/RW 09/01, Tuntang, Kabupaten Semarang, Jawa Tengah. Metode yang digunakan adalah kualitatif secara observasi yang dilakukan dalam bentuk wawancara terstruktur secara langsung dan menggunakan google form. Data yang didapat kemudian digabungkan sehingga menjadi pembahasan secara deskriptif. Berdasarkan hasil penelitian ini orang tua "GM" melakukan upaya penanganan dengan cara mendisiplin sesuai aturan, melatih meningkatkan perkembangan, memberikan motivasi berupa apresiasi, memberi batasan/aturan, membawa "GM" untuk pemerikasaan pendengaran, mengikutkan terapi, memasukkan ke sekolah formal yang umum serta melatih beberapa tips dari pakar ABK di rumah. Hasil perkembangan "GM" terlihat signifikan, contohnya sudah mampu mengucapkan huruf-huruf serta mulai berkata-kata sederhana. Sosio emosional "GM" juga mulai berkembang baik, dapat mengungkapkan pikiran, mulai fokus, dan mampu menatap mata orang lain. Dengan demikian, pola asuh otoritatif dinyatakan tepat untuk menangani anak berkebutuhan khusus kategori gifted.
\end{abstract}

Kata Kunci: pola asuh, anak berkebutuhan khusus (ABK), sulit berbicara, gifted, autis

\begin{abstract}
Children with special needs have a variety of cases. This study will focus on discussing the development of children with special needs based on authoritative parenting. The goal is that parents can understand the types and factors that cause children with special needs in the gifted category, so they can pay attention to child care appropriately. This research was conducted in October 2020 - July 2021 Lopait Village RT/RW 09/01, Tuntang, Semarang Regency, Central Java. The method used is qualitative observation conducted in the form of direct structured interviews and using google form. The data obtained are then combined so that it becomes a descriptive discussion. Based on the results of this study, "GM" parents made efforts to handle it by disciplinary action according to the rules, training to improve development, providing motivation in the form of appreciation, giving limits/rules, bringing "GM" for hearing checks, participating in therapy, entering public formal schools and practice some tips from $A B K$ experts at home. The results of the development of "GM" look significant, for example, being able to pronounce letters and starting to say simple words. Socio-
\end{abstract}


emotional "GM" also begins to develop well, can express thoughts, begin to focus, and is able to look into the eyes of others. Thus, authoritative parenting is said to be appropriate for dealing with children with special needs in the gifted category.

Keywords: Parenting, Children with Special Needs, Difficulty in Speaking, Gifted, Autism.

\section{Pendahuluan}

Setiap anak memiliki tahap perkembangan yang berbeda. Tetapi mayoritas masyarakat memiliki pandangan yang berbeda, dengan demikian mengelompokkan anak dengan tahap perkembangan berbeda dengan sebutan anak berkebutuhan khusus. Definisi yang serupa dipaparkan oleh Heward, bahwa anak yang memiliki karakteristik yang berbeda dengan anak lainnya meskipun tidak menunjukkan ketidakmampuan fisik, mental, atau emosi adalah kategori anak berkebutuhan khusus. ${ }^{1}$ Tetapi hal ini bertolak belakang dengan Peraturan Menteri Pemberdayaan Perempuan dan Perlindungan Anak No 10 Tahun 2011 yang menyatakan anak berkebutuhan khusus adalah anak yang mengalami keterbatasan fisik, mental, intelektual, sosial maupun emosional yang berpengaruh secara signifikan dalam proses pertumbuhan serta perkembangan dibandingkan dengan anak-anak lain seusia dengannya. ${ }^{2}$

Pada umumnya, ABK juga sering disebut anak autis dan anak istimewa. Anak autis memiliki berbagai jenis sesuai dengan ciri-ciri dan perkembangannya, demikian juga anak istimewa. Menurut Chris Wiliiams dan Barry Wright anak autis atau Gangguan Spektrum Autisme

\footnotetext{
1 Hendra Jaya, "Keterampilan Vokasional Bagi Anak Berkebutuhan Khusus Perawatan Dan Perbaikan Alat Elektronika" (Fakultas MIPA universitas negeri makassar, 2017).

2 Wahyu Hartono, Profil Anak Berkebutuhan Khusus (ABK) (Jakarta, 2014).
}

(Autism Spectrum Disorder) adalah gangguan perkembangan pada anak yang umum tampak di usia tiga tahun pertama kehidupan anak. Selanjutnya, diperkirakan ASD termasuk spektrum yang didiagnosa terdapat pada dua sampai tujuh per 1000 orang. Sepersepuluh di antaranya ada pada tingkat keparahan terburuk spektrum autisme. Sekitar tiga sampai empat kali lebih beresiko pada anak laki-laki dari pada anak perempuan. ${ }^{3}$ Jadi masyarakat umum juga perlu memahami ciri anak berkebutuhan khusus karena perkembangan zaman menunjukkan bahwa tanda-tanda anak berkebutuhan khusus makin bermunculan.

Pemahaman orang tua yang terlibat dalam pendidikan juga perlu diedukasi sehingga dapat lebih mudah memberikan penanganan yang tepat untuk tumbuh kembang anak. Secara khusus dalam pendidikan anak usia dini yang memonitoring secara langsung tumbuh kembang anak pada tiga tahun pertama (1000 hari pertama). Tujuannya adalah agar dapat mendeteksi sejak awal perbedaan tumbuh kembang yang ditemukan dan menolong sedini mungkin dalam perkembangan anak.

Hurlock juga memaparkan perkembangan merupakan hasil proses kematangan dan belajar ${ }^{4}$ maka sangat penting memahami perkembangan anak

\footnotetext{
${ }^{3}$ Chris Williams dan Barry Wright, How To Live, With Autism and Asperger Syindrome (Jakarta: PT Dian Rakyat, 2007), 3.

4 Elizabeth B. Hurlock, Perkembangan Anak (Jakarta, 2005), 28.
} 
sejak awal agar dapat memaksimalkan potensi anak. ${ }^{5}$ Sedangkan Anak yang berbeda perkembangannya dikenal dengan istilah anak cerdas istimewa (gifted children). Cerdas istimewa merupakan istilah yang digunakan bagi seorang anak yang memiliki kecerdasan di atas rata-rata anak seusianya. ${ }^{6}$ Anak gifted yang memiliki kemampuan kecerdasan diatas rata-rata $(130-140)^{7}$, tidak serta merta menyenangkan karena seringkali orang pada umumnya sulit menerima anak-anak tersebut dan dianggap tidak normal seperti yang lain. Selanjutnya Julia menjelaskan bahwa anak perlu mendapat deteksi saat balita untuk melihat anak memiliki indikasi cerdas istimewa. $^{8}$

Data Badan Pusat Statistik (BPS) tahun 2017 memaparkan jumlah ABK di Indonesia mencapai 1,6 juta orang dan $70 \%$ ABK belum mendapat Pendidikan yang layak. Selanjutnya, dari $30 \%$ data ABK yang sudah memperoleh pendidikan, hanya $18 \%$ yang sudah menerima pendidiikan inklusi, baik di sekolah luar biasa (SLB), maupun sekolah biasa pelaksana pendidikan inklusi. ${ }^{9}$ Oleh

\footnotetext{
5 Santosa Santosa, "Urgensi Peran Orang tua Membangun Kepemimpinan Anak Di Era Disrupsi Teknologi Berdasarkan Ulangan 6: 6-9," EDULEAD: Journal of Christian Education and Leadership 2, no. 1 (June 1, 2021): 71-88, https://stak-pesat.ac.id/ejournal/index.php/edulead/article/view/61.

6 Julia Maria Van Tiel dan Endang Widyorini, Anak Cerdas Istimewa (Jakarta: Prenadamedia Group, 2014), 2.

7 Aliva Humairah Br Ginting dan Ichsan Ichsan, "Pola Asuh Orang tua Pada Anak Cerdas Dan Anak Gifted," El Midad 13, no. 1 (2021): 1-9.

${ }^{8}$ Tiel dan Widyorini, Anak Cerdas Istimewa, 2.

9 Tika Anggreni Purba, "70 Persen Anak Berkebutuhan Khusus Tak Dapat Pendidikan Layak," Bisnis.Com (Jakarta, 2019), https://lifestyle.bisnis.com/read/20190326/236/90 4431/70-persen-anak-berkebutuhan-khusus-takdapat-pendidikan-layak.
}

sebab itu pemahaman orang tua juga berpengaruh terhadap penanganan kasus anak berkebutuhan khusus karena memiliki peran yang besar terkait kehidupan sosial anak ${ }^{10}$ pada masa perkembangan anak usia dini atau masa keemasan (golden age) dimana terjadi perkembangan pesat dalam hal fisik dan psikis. ${ }^{11}$ Selain itu, dalam memonitoring tumbuh kembang anak. ${ }^{12}$ Apalagi dalam Era Covid-19 yang mengharuskan orang bergerak dari manual menuju era digital, untuk itu semua proses kehidupan dapat dilakukan di rumah. ${ }^{13}$ Jika semua aktifitas dapat dikerjakan di rumah, maka akan dengan sangat mudah orang tua mementoring tumbuh kembang anak atau memberikan pengasuhan yang tepat dalam lingkungan keluarga, karena akan selalu bersama dengan anak. Jika pengasuhan yang dilakukan kurang tepat, maka ada dampak yang terjadi untuk selanjutnya. Wijanarko menjelaskan bahwa akibat pengasuhan yang salah adalah sebagai berikut ${ }^{14}$ : anak menjadi acuh dan cuek pada lingkungan, anak akan menarik diri dari pergaulan, anak akan menjadi egois, anak tidak bertanggungjawab, anak memiliki sikap

\footnotetext{
${ }^{10}$ Kosma Manurung, "Mencermati Arti Penting Penggunaan Bahasa Cinta Anak Dalam Keluarga Kristen Di Era 5.0," EDULEAD: Journal of Christian Education and Leadership 2, no. 1 (June 1, 2021): 53-70, https://stak-pesat.ac.id/ejournal/index.php/edulead/article/view/53.

11 Sozanolo Telaumbanua dan Desi Sianipar, "Patriotisme Kristen," Jurnal Shanan 5, no. 1 (March 30, 2021): 61-78, http://ejournal.uki.ac.id/index.php/shan/article/vie w/2734.

12 Jaya, "Keterampilan Vokasional Bagi Anak Berkebutuhan Khusus Perawatan Dan Perbaikan Alat Elektronika."

${ }^{13}$ Masrul, Pandemik COVID-19 Persoalan Dan Refleksi Di Indonesia (Surabaya: Yayasan Kita Menulis, 2020), 40.

14 Djarot Wijanarko, Intim Orang tua - Anak (Jakarta, n.d.), 210.
} 
pemberontak. Maka mengasuh anak dengan tepat menjadi sangat diperlukan sehingga anak-anak kelak bertumbuh dengan sikap. Sikap yang diajarkan dalam Kristiani adalah sikap mengasihi sesuai dengan syema Israel dalam kitab Ulangan 6:4-5. Pola asuh berdasarkan pendidikan agama Kristen mampu menghasilkan keluarga yang memiliki karakter serta memiliki nilai-nilai kekristenan, seperti kepedulian dan kasih. ${ }^{15}$ Pola asuh yang menjadi salah satu tindakan dalam mewujudkan pelayanan kasih.

Pemahaman orang tua serta perbedaan pendapat tentang anak berkebutuhan khusus menjadi salah satu faktor yang menyebabkan orang tua menjadi sulit memberikan penanganan yang tepat terhadap anak yang berkebutuhan khusus. ${ }^{16}$ Akhirnya anakanak yang memiliki tumbuh kembang berbeda dari anak umumnya akan mengalami kesulitan dalam menjalani kehidupannya, dalam hal ini yang akan dibahas lebih spesifik adalah kesulitan bicara. Lebih lanjut, bagi sebagian orang tua berlatar belakang pendidikan yang maju, akan mengerti kondisi anak dengan tingkat perkembangan berbeda, namun bagi orang tua yang terbatas pendidikan dan pengetahuan, kemungkinan akan menganggap anaknya sebagai "aib" dalam keluarga.

15 Djoys Anneke Rantung, "Pendidikan Agama Kristen Untuk Keluarga Menurut Pola Asuh Keluarga Ishak Dalam Perjanjian Lama," Jurnal Shanan 3, no. 2 (October 28, 2019): 63-76, http://ejournal.uki.ac.id/index.php/shan/article/vie w/1579.

16 Miftakhul Jannah, "Studi Deskripsi : Perekonomian Orang tua Anak Berkebutuhan Khusus Terhadap Pendidikan Anak Berkebutuhan Khusus," SPECIAL: Special and Inclusive Education Journal 1, no. 1 (May 14, 2020): 4958 ,

http://jurnal.unipasby.ac.id/index.php/special/artic le/view/2293.
Berdasarkan observasi terhadap
anak dengan insial "GM", "GM" termasuk anak berkebutuhan khusus dengan praduga kategori anak Gifted. Alasan disebut anak gifted karena pada usia sampai tiga tahun empat bulan "GM" belum berbicara seperti anak pada umumnya. Selanjutnya perkembangan yang lain, sisi sosio emosionalnya mengalamai keterlambatan, belum mampu diajak bercanda dengan teman sebayanya, takut dengan keramaian, takut dengan lilin dan balon. Padahal bagi anak lain, usia anak sekitar empat tahun, biasanya suka balon, tetapi "GM" takut dengan balon. Perkembangan emosi "GM" mengalami hambatan, pada waktu harusnya anak menangis, "GM" tidak menangis namun ketika ada hal-hal yang sederhana, "GM" bisa menangis. Demikianlah beberapa tanda "GM" kemungkinan masuk dalam kategori gifted namun hal tersebut belum bisa dipastikan karena "GM" terus mengalami perkembangan. Tujuan penelitian ini adalah menolong para orang tua memahami jenis dan faktor penyebab anak berkebutuhan khusus kategori gifted agar dapat melakukan penanganan yang sesuai dalam hal pengasuhan terhadap anak berkebutuhan khusus. Secara khusus pada pola asuh otoritatif yang memacu anak untuk menjadi pribadi yang mandiri dengan menetapkan batas-batas pengendalian pada tindakan-tindakan yang dilakukan.

\section{Metode Penelitian}

Metode yang digunakan adalah kualitatif yaitu penelitian yang dilakukan pada situasi alamiah dan berlandaskan pada filsafat postpositivistik serta bersifat 
seni karena kurang terpola. ${ }^{17}$ Pendekatan penelitian dilakukan dengan kualitatif agar dapat menyelidiki fenomenal yang terjadi secara alamiah tentang penanganan anak berkebutuhan khusus kategori gifted secara mendalam dan detail sehingga bertumbuh secara optimal. Selanjutnya, data-data yang diperoleh akan dipaparkan secara rinci dalam bentuk deskripsi, seperti dipaparkan oleh Russel K. Shcutt bahwa ciri khas penelitian kualitatif adalah paparan hasil berupa teks deskripsi, bukan angka. ${ }^{18}$ Data yang didapat harus mendalam sehingga mengandung makna sesuai tujuan penelitian.

Pengumpulan data dilakukan menggunakan cara observasi dalam bentuk wawancara terstruktur ${ }^{19}$ kepada 9 orang responden yang terdiri dari orang tua dan pendamping "GM" sebagai sumber primer penelitian. Dalam penelitian ini, peneliti sebagai observer partisipasi aktif melakukan observasi secara langsung dengan cara mengamati perkembangan Anak Berkebutuhan Khusus (ABK) kategori anak Gifted. Selain itu melakukan wawancara kepada kedua orang tua "GM" dan 7 orang dewasa yang turut mendampingi tumbuh kembang "GM" dengan menggunakan google form dikarenakan masih masa pandemi dan pembatasan pertemuan secara langsung sehingga dapat mengumpulkan informasi lebih cepat dan terdokumentasi secara deskripsi.

Analisa data dilakukan dengan tahap awal mengumpulkan data melalui observasi langsung terhadap "GM" dan

\footnotetext{
17 Sugiyono, Metode Penelitian Kuantitatif Dan Kualitatif Dan $R \& D$ (Bandung: ALFABETA, 2011), 7.

18 Cosmas Gatot Haryono, Ragam Metode Penelitian Kualitatif Komunikasi (Sukabumi: CV Jejak, 2020), 101.

${ }^{19}$ Haryono, 108.
}

cara yang digunakan orang tua dan wawancara dengan 9 orang kunci dalam penelitian. Setelah melakukan observasi dan wawancara serta dokumentasi, maka data yang ada digabungkan atau melakukan triangulasi dan mengambil penarikan kesimpulan terhadap hasil data penelitian. $^{20}$

\section{Hasil dan Pembahasan \\ A. Landasan Alkitab}

Bersumber pada hukum utama umat Kristiani tentang kasih dalam injil Matius, Markus, Lukas dan Yohanes serta shema Israel dalam Ulangan 6:4-5 dapat dikaji spiritualitas Yesus. ${ }^{21}$ Berlandaskan kasih, kemudian Yesus melakukan mujizat-mujizat sebagai salah satu sarana penginjilan. $^{22}$ Hal ini juga menjadi peluang bagi pelayanan kasih yang diwujudkan kepada sesama manusia sesuai dengan hukum kasih yang kedua. Cara mengasihi orang lain seperti diri sendiri dapat dilakukan dalam banyak hal, satu diantaranya dalam bentuk pendidikan bagi anak berkebutuhan khusus. ${ }^{23}$ Kisah Raja Daud dalam menjamu Mefiboset yang cacat (2 Samuel 9:3-7) juga menjadi salah satu gambaran bagaimana kasih Daud kepada Yonatan tersalurkan kepada keturunannya. Meskipun Mefiboset

\footnotetext{
${ }^{20}$ Albi Anggito dan Johan Setiawan, Metodologi Penelitian Kualitatif (Sukabumi: CV Jejak, 2018), 244.

${ }^{21}$ Nur Fitriyana, "Spritualitas Yesus : Mengasihi Sesama Seperti Mengasihi Diri Sendiri,” Jurnal Ilmu Agama: Mengkaji Doktrin, Pemikiran, dan Fenomena Agama 18, no. 2 (December 30, 2017), http://jurnal.radenfatah.ac.id/index.php/JIA/article /view/2370.

22 Hannas Hannas dan Rinawaty Rinawaty, "Menerapkan Model Penginjilan Pada Masa Kini," KURIOS (Jurnal Teologi dan Pendidikan Agama Kristen) 5, no. 2 (2019): 175-189.

23 Antonius Isharjono, "Menerapkan Pola Pendidikan Rohani Anak Berkebutuhan Khusus (Attention Deficit or Hyperactivity Disorder)," Jurnal Teruna Bhakti 2, no. 1 (2019): 37-48.
} 
adalah seorang yang timpang kakinya (2 Sam 9:3). Sudah selayaknya pelayanan kasih dapat kita nyatakan kepada sesama kita. Dalam kajian ini akan membahas lebih jauh tentang bagimana wujud kasih dalam keluarga yang dinyatakan dalam pola Asuh orang tua kepada anak berkebutuhan khusus.

\section{B. Tipe Pola Asuh}

Pola asuh terdiri dari dua kata, pola dan asuh. Dalam kamus besar bahasa Indonesia, Pola berarti gambar yang dipakai untuk contoh ${ }^{24}$ Sedangkan asuh adalah membimbing, memimpin dan menjaga. ${ }^{25}$ Dengan demikian pola asuh didefinisikan sebagai usaha orang tua dalam menjaga, membimbing dan memimpin anak sehingga bertumbuh menjadi pribadi yang dewasa dan berkarakter. $^{26}$ Tidak hanya itu, Al Tridhonanto memaparkan pola asuh orang tua adalah seluruh interaksi orang tua dan anak, hal ini dapat berupa dorongan untuk mengubah pengetahuan, tingkah laku dan nilai yang dianggap paling tepat bagi anak sehingga menjadi lebih mandiri, sehat, percaya diri, memiliki sifat rasa ingin tahu, bersahabat serta berorientasi sukses. $^{27}$ Selaras dengan pendapat Subyakto Atmosiswoyo dan Harmiwati Subyakto bahwa pola asuh adalah pembentukan perilaku generasi selanjutnya sesuai norma dan nilai yang

${ }^{24}$ Departemen Pendidikan Nasional, Kamus Besar Bahasa Indonesia (Jakarta: Balai Pustaka, 2002), 884.

${ }^{25}$ Departemen Pendidikan Nasional, 73.

26 Ida Destariana Harefa dan Ahmad Tabrani, "Problematika Pendidikan Karakter, Antara Konsep Dan Realita," SHAMAYIM: Jurnal Teologi dan Pendidikan Kristiani 1, no. 2 (May 5, 2021): 148-156, http://sttybmanado.ac.id/ejournal/index.php/shamayim/article/view/23.

${ }^{27}$ Al Tridonanto dan Beranda Agency, Pola Asuh Demokratis (Jakarta: Gramedia, 2014), 5. dianggap baik dan sesuai dengan yang berlaku di masyarakat dan keluarga. ${ }^{28}$ Edwards juga memaparkan norma yang berlaku di masyarakat sangat berpengaruh terhadap proses pola asuh keluarga. ${ }^{29}$ Dengan demikian pola yang diterapkan dalam setiap keluarga tentunya berbeda. Pola ini juga dipengaruhi oleh faktor keturunan juga budaya yang berlaku. Dapat terjadi perbedaan-perbedaan dalam pola asuh sesuai dengan budaya yang dianut dalam keluarga tersebut. Hal ini tentunya membawa pengaruh yang berbeda juga dalam membentuk nilai serta perilaku anak. Pola yang dilakukan dalam keluarga juga dapat membentuk pola asuh yang sama untuk keluarga baru yang akan terbentuk nantinya.

Dalam pandangan Kristen, Susan S. Wiriadinata dalam buku Mengasuh Anak, Mengasihi Tuhan mengemukakan dasar yang digunakan Alkitab terkait pola asuh merupakan perintah Tuhan kepada orang tua agar mengajari anak-anaknya mengenal Allah yang disertai dengan cara pengajaran secara berulang dan berlaku di setiap tempat dan waktu serta dengan kemampuan maksimal, termasuk menjadi teladan sesuai dengan kitab Ulangan $6 .{ }^{30}$

Jadi, dari beberapa pendapat dapat disintesiskan pola asuh adalah seluruh interaksi orang tua dalam memotivasi, mendidik, membimbimbing, mendisiplin, dan melindungi anak untuk mencapai kedewasaan yang dilakukan secara berulang di setiap tempat dan waktu dengan segenap kemampuan, termasuk dalam bentuk menjadi teladan agar berkenan di hati Tuhan.

\footnotetext{
28 Hardywinoto dan Tony Setiabudhi, Anak Unggul Berotak Prima (Jakarta, 2003), 212.

${ }^{29}$ Tutik Hidayati, Pendamping Gizi Pada Balita (Yogyakarta, 2019), 13.

30 Susan S Wiriadinata, Mengasuh Anak Mengasihi Tuhan (Jakarta, 2018), 2.
} 
Pengasuhan anak yang dilakukan orang tua tentu berbeda-beda, hal tersebut secara tidak langsung dipengaruhi oleh cara orang tuanya dibesarkan sebelumnya. Berikut akan dijabarkan tipe-tipe pola asuh secara lebih spesifik. Pertama, pola asuh otoriter yang bersifat keras dan ketat $^{31}$ dengan gaya menetapkan batasan dan menghukum serta menuntut anak untuk mengikuti perintah orang tua serta menghormati pekerjaan dan usaha. Cirinya: orang tua menetapkan batasan tegas, tidak memberi kesempatan untuk anak berbicara menyampaikan pendapat, sehingga anak memiliki ketrampilan komunikasi yang rendah.

Kedua, pola asuh otoritatif atau demokratif. Pola asuh Otoritatif bersifat mengupayakan serta memotivasi anak agar mandiri dengan menetapkan batasan pengendalian atas tindakan yang dilakukan. Pola asuh otoritatif juga mengutamakan kesamaan hak serta kewajiban namun masih memiliki batasan-batasan yang jelas. ${ }^{32}$ Jadi, anak mampu mengontrol prilakunya sesuai dengan norma yang berlaku di masyarakat. ${ }^{33}$ Cirinya: memiliki diskusi verbal yang ekstensif dimungkinkan, memberi kehangatan serta kasih kepada anak dalam setiap tindakan yang dilakukan. $^{34}$ Pola asuh Otoritatif merupakan pola yang diterapkan dalam penanganan anak berkebutuhan khusus inisial "GM" kategori gifted.

31 Andris Noya, Pendidikan Papa Mama, ed. Abdul (Penerbit Adab, 2020), 22.

32 Noya, 29.

${ }^{33}$ Siti Rohimah, Ari Sofia, dan Susanthi Pradini, "Hubungan Pola Asuh Otoritatif Terhadap Kemandirian Anak Usia 5-6 Tahun," Jurnal Pendidikan Anak 5, no. 1 (2019).

34 Aprilia Tina Lidyasari, "Pola Asuh Otoritatif Sebagai Sarana Pembentukan Karakter Anak Dalam Setting Keluarga," Yogyakarta: PGSD FIP UNY (2013).
Ketiga, pola asuh permisif yang memberi kebebasan penuh kapada anak untuk mengekspresikan keinginannya serta tidak memberi batasan-batasan. ${ }^{35}$ Pola asuh permisif lebih bersifat memanjakan anak $^{36}$ sehingga anak menjadi kurang terkontol. Cirinya: memanjakan anak, memberi kebebasan penuh kepada anak.

\section{Anak Berkebutuhan Khusus}

Peraturan Menteri memaparkan deteksi dini pada anak-anak yang berkebutuhan khusus memang masih mengalami kesulitan untuk dimasukkan dalam jenis-jenis kelompoknya. Julia Van Tiel mengatakan sering membaca laporan bahwa satu anak bisa mendapatkan diagnosis yang berbeda-beda dari tenaga kesehatan ataupun psikolog yang berbeda ${ }^{37}$ Dengan diagnosa yang berbedabeda maka akan menyulitkan orang tua untuk menangani secara berkelanjutan, maka sangat baik jika orang tua juga belajar baik melalui buku-buku maupun artikel-artikel yang akan menolong memberikan pemahaman cukup tentang perkembangan anak-anak.

Mangunsong mendefinisikan anak berkebutuhan khusus adalah anak yang pertumbuhannya tidak sesuai dari ratarata anak normal baik secara mental, kemampuan sensorik, fisik dan neuromaskular, perilaku sosial dan emosial, berkomunikasi maupun kombinasi dari hal tersebut. ${ }^{38}$ Hal ini berarti, anak yang berkebutuhan khusus

35 Siti Nur Aidah, Tips Menjadi Orang tua Inspirasi Masa Kini (Yogyakarta: KBM Indonesia, 2020), 2.

${ }^{36}$ Noya, Pendidikan Papa Mama, 33.

37 Julia Maria Van Tiel dan Endang Widyorini, Anak Cerdas Istimewa (Jakarta, 2014), 9.

${ }^{38}$ Ni'matuzahroh dan Yuni Nurhamida, Individu Berkebutuhan Khusus Dan Pendidikan Inklusif (Malang: UMM, 2016), 1. 
bukan hanya anak yang memiliki ciri tumbuh kembang di bawah rata-rata atau cepat dari semestinya, termasuk gabungan dari beberapa aspek sekaligus. Dalam hal ini, orang tua juga dituntut memahami tumbuh kembang anak normal agar dapat memahami apakah anak berkebutuhan khusus atau tidak.

Berbeda dengan pandangan Mangunsong, Hallahan dan Kauffman memaparkan anak berkebutuhan khusus perlu pendidikan khusus serta layanan terkait. $^{39}$ Artinya ciri yang berbeda dengan tumbuh kembang normal pada anak belum cukup untuk mengategorikan anak berkebutuhan khusus selama anak tersebut tidak memerlukan pendidikan khusus serta layanan terkait. Anak dengan tumbuh kembang yang tidak normal, selama masih belum membutuhkan layanan dan pendidikan khusus belum dikategorikan sebagai anak berkebutuhan khusus. Gearheart dalam Mangunsong juga mengemukakan pandangan serupa dengan hal tersebut. Anak yang membutuhkan pendidikan berbeda dengan anak rata-rata normal untuk dapat belajar efektif adalah anak berkebutuhan khusus. $^{40}$

\section{Jenis Anak Berkebutuhan Khusus}

Sebelum membahas secara spesifik anak berkebutuhan khusus kategori gifted penting bagi pembaca mengetahui jenis anak berkebutuhan khusus agar dapat mebedakan dengan kategori gifted. Berikut ini pengertian dari beberapa jenis anak berkebutuhan khusus: ${ }^{41}$

- Attention Deficit Hyperactivity
Disorder (ADHD) atau Gangguan
Pemusatan Perhatian dan

${ }^{39}$ Ni'matuzahroh dan Nurhamida.
${ }^{40}$ Ni'matuzahroh dan Nurhamida.
${ }^{41}$ Tiel dan Widyorini, Anak Cerdas Istimewa, 75.

Hiperaktivitas (GPPH) yang merupakan gangguan perilaku paling banyak terjadi pada anak-anak. ADHD terjadi pada gangguan neurologis, anak ADHD mengalami masalah dalam belajar, kehidupan keluarga, kontak social, dan dalam fungsi emosi.

- Autisma infantil atau Autisma masa kanak-kanak merupakan kelainan yang dialami pada masa anak-anak sebelum usia lima tahun, mengalami perkembangan bahasa yang tidak normal, mengalami gangguan perkembangan bicara.

- Gifted merupakan anak dengan kecerdasan yang istimewa, dengan IQ 130-140. ${ }^{42}$ Tentu saja hal ini berbeda dengan tipe anak berkebutuhan khusus lainnya meskipun masih banyak yang menyamakan autisme dengan gifted.

Phil Christhie dan kawan-kawan mengatakan bahwa secara umum, anak berkebutuhan khusus yang sering disebut anak autis memiliki ciri khusus yang mendasar berupa sulit merasakan empati sosial berupa pemahaman pendapat, bahasa, emosi dan tingkah laku. ${ }^{43}$ Phil juga menjelaskan bahwa anak autis memiliki tingkat keparahan yang berbeda disebut sebagai "kelainan spektrum". Hal ini bisa ditandai dengan memiliki tingkat intelegensi yang tinggi atau justru mengalami kesulitan belajar. Ada tiga area yang menjadi kesulitan bagi anak autis yaitu kesulitan bahasa atau komunikasi, interaksi sosial atau pemahaman terhadap sekitarnya serta

\footnotetext{
${ }^{42}$ Ginting Dan Ichsan, "Pola Asuh Orang tua Pada Anak Cerdas Dan Anak Gifted."

43 Phil Christie, Langkah Awal Berinteraksi Dengan Anak Autis (Jakarta: Kompas Gramedia, n.d.), 7.
} 
kurang fleksibel dalam berpikir serta berperilaku. $^{44}$

Thompson dan Henderson menuliskan 9 garis besar kebutuhan layanan bimbingan konseling untuk anak berkebutuhan khusus: 1) anak mengenal dirinya sendiri, 2) menemukan kebutuhan yang spesifik, 3) menemukan konsep diri, 4) Memfasilitasi sesuai kebutuhan 5) berkoordinasi dengan ahli lain, 6) melakukan konseling terhadap keluarga anak berkebutuhan khusus, 7) membantu perkembangan anak berkebutuhan khusus agar berkembang efektif, memiliki keterampilan hidup mandiri, 8) membuka peluang kegiatan rekreasi dan mengembangkan hobi, dan 9) mengembangkan keterampilan personal dan sosial. ${ }^{45}$

\section{E. Faktor Penyebab Berkebutuhan Khusus Kategori Gifted}

Gangguan pada anak berkebutuhan khusus memiliki faktor penyebab. Pada Anak Berkebutuhan Khusus kategori gifted penyebab yang mendominasi adalah faktor genetik. ${ }^{46}$ Pada jenis gangguan kesulitan belajar, hasil penelitian mengemukakan $35-45 \%$ anak yang memiliki kesulitan belajar juga memiliki orang tua dan saudara yang mengalami kesulitan belajar. ${ }^{47}$ Penelitian di Inggris memaparkan sebanyak 3\% anak terlambat berbicara karena gangguan ekspresif. Sedangkan penelitian USA mendapati $7,4 \%$ dengan kemungkinan laki-laki $8 \%$ dan perempuan $6 \%{ }^{48}$

\footnotetext{
${ }^{44}$ Christie, 8.

45 Rafael Lisinus dan Pastiria Sembiring, Pembinaan Anak Berkebutuhan Khusus (Medan: Yayasan Kita Menulis, 2020), 5.

${ }^{46}$ Tiel dan Widyorini, Anak Cerdas Istimewa, 75.

${ }^{47}$ Tiel dan Widyorini.

48 Julia Maria Van Tiel, Pendidikan Anakku Terlambat Bicara (Jakarta: PRENADA, 2011), 41.
}

Meskipun demikian, Njiokiktjien dengan jelas memaparkan melalui penelitiannya bahwa faktor yang dapat disimpulkan adalah karena faktor genetik atau keturunan. $^{49}$ Pada anak berkebutuhan khusus kategori gifted keterlambatan bicara menjadi ciri yang sering muncul.

\section{F. Cara Penanganan Anak Gifted}

Penanganan anak berkebutuhan khusus selalu berbeda sesuai dengan jenisnya. Namun penanganan yang dilakukan dapat dikelompokkan menjadi tiga bagian. Pertama, layanan medis agar anak memperoleh layanan kesehatan yang sesuai dengan tumbuh kembang anak di posyandu, pos kesehatan desa, puskesmas, rumah sakit serta dokter praktik lainnya. ${ }^{50}$ Kedua, layanan pendidikan sehingga dengan kekhususan beragam anak tetap bisa belajar sesuai tahapan. Oleh karena itu, layanan pendidikannya menyesuaikan dengan karakteristik yang dimiliki dan kebutuhan anak. $^{51}$ Ketiga, layanan fisik yang berhubungan langsung dengan kebutuhan anak serta sarana dan prasarana. ${ }^{52}$

\section{G. Gambaran anak berkebutuhan khusus ananda "GM"}

"GM" adalah anak pertama dari keluarga yang menikah pada usia 30an tahun dengan pengalaman yang masih sangat kurang sebagai orang tua awal. Kelahiran "GM" melalui proses normal dengan bantuan vakum tingkat sedang. Pertumbuhan "GM" di tahun pertama sama seperti perkembangan anak yang lain. Pada usia "GM" yang ke dua, kekuatiran orang tua menjadi muncul

\footnotetext{
49 Tiel., 43.

50 Hartono, Profil Anak Berkebutuhan Khusus (ABK), 23.

${ }^{51}$ Hartono, 24.

${ }^{52}$ Hartono, 29.
} 
karena belum menunjukkan perkembangan bicara secara normal. Muncul banyak pemikiran dan solusi yang dicari. Awalnya membawa "GM" ke RSUD Karyadi Semarang mengikuti tes BERA, tes syaraf pendengaran dan hasilnya bagus tidak ada masalah dalam pendengaran. Orang tua juga selalu berusaha mengajari "GM" namun belum menunjukkan perkembangan yang signifikan. Suatu kali "GM" minta susu, kemudian menunjuk namun belum mau bicara jadi orang tua memberikan jika "GM" mau bicara tetapi "GM" pilih tidak minta susu lagi daripada disuruh bicara.

"GM" sampai pada usia tiga tahun dan belum berbicara, waktu tersebut menjadi sangat lama buat orang tua yang menunggu anak mengucapkan satu kata "mama" dari mulutnya. Walaupun ada banyak perkembangan lain yang "GM" lakukan namun sebagai orang tua belum memahami hal yang demikian. Mungkin karena fokus hanya pada bicara sehingga yang lain tidak diperhatikan. Sepakat untuk membawa "GM" kembali terapi ke rumah pintar di Salatiga. Tiga hari awal merupakan waktu yang sulit untuk "GM" karena dipaksa berpisah dengan orangtua ketika belajar sehingga setiap kali terapi selama tiga hari selalu menangis. Orang tua harus belajar untuk "tega" meninggalkan "GM" dengan pembimbing walaupun sangat sedih mendengar suara tangis "GM". Ternyata rasa "tega" orang tua membuahkan hasil, pada hari berikutnya "GM" sudah tidak menangis dan mau terapi dengan pembimbing, orangtua sangat bersyukur. Semakin lama "GM" menikmati terapi dan senang ketika diantar ke tempat terapi.

Setiap kali orang tua minta "GM" menirukan, selalu diam dan seperti tidak ada usaha mencoba, memang orangtua sudah putus asa pada waktu itu. Orang tua selalu mengomunikasikan perilaku dan perkembangan "GM" kepada kepala rumah pintar tempat terapi. Orang tua diajari untuk melakukan beberapa hal di rumah. 1) "GM" perlu diajari meniup terompet, tetapi setelah orang tua coba, "GM" malah takut dengan suara terompet. 2) "GM" perlu diajari tiup peluit, juga sudah coba dan sama hasilnya tidak mau dengan suaranya. 3) "GM" perlu diajari untuk meniup lilin, namun nihil juga karena pada usia sebelum dua tahun, "GM" sudah takut dengan lilin. Ketakutan "GM" dengan lilin, menurut orang tua tidak masuk akal bahkan waktu ulang tahun "GM" yang ke dua, dan ke tiga, "GM" tidak mau meniupnya. Orang tua sangat tidak mengerti hal tersebut dan yang membuat lucu adalah "GM" mencoba mematikan lilin dengan menggunakan kayu yang panjang. Dan yang terakhir, "GM" perlu diajari meniup kapas, ternyata "GM" mau sehingga setiap hari kami selalu minta "GM" tiup kapas. Walaupun belum bicara, selalu kenalkan huruf-huruf, angka, dan selalu diajarkan berulang- ulang.

\section{H. Penanganan yang sudah dilakukan untuk GM}

Orang tua membawa GM untuk periksa pendengaran yaitu Tes BERA untuk memastikan apakah ada kelainan pada alat pendengaran di RS Kariadi Semarang, kemudian dibawa konsultasi ke psikolog dan orang tua sering sharing dengan ibu-ibu serta rekan-rekan di komunitas sehingga dapat dukungan penuh para ibu dan rekan-rekan. "GM" juga dibawa ke tempat terapi bicara setiap 2 kali seminggu selama hampir satu tahun. Untuk mengatasi ketakutan tiup lilin, orang tua melatih mulai meniup kapas perlahan

Penanganan yang dilakukan sudah berusaha semaksimal mungkin untuk meningkatkan perkembangan 
"GM" lewat terapi, konseling dengan konselor-konselor yang orang tua "GM" kenal, menyekolahkan "GM" di sekolah khusus dan menstimulasi perkembangan "GM" dengan membangun interaksi dan komunikasi yang baik. Pemberian hukuman untuk "GM" karena melanggar batasan (menggunakan HP melewati batas waktu yang disepakati dengan orang tuanya).

\begin{tabular}{|l|l|c|c|c|}
\hline \multirow{2}{*}{ No } & \multirow{2}{*}{ Indikator } & \multicolumn{3}{|c|}{ Persentase Hasil Wawancara } \\
\cline { 3 - 5 } & SS & KS & TS \\
\hline 1 & Mendisiplin Sesuai Aturan & $77,78 \%$ & $11.11 \%$ & $11,11 \%$ \\
\hline 2 & Melatih Meningkatkan Perkembangan & $100 \%$ & $0 \%$ & $0 \%$ \\
\hline 3 & Memberikan Motivasi Berupa Apresiasi & $100 \%$ & $0 \%$ & $0 \%$ \\
\hline 4 & Memberi Batasan/Aturan & $77,78 \%$ & $22.22 \%$ & $0 \%$ \\
\hline 5 & $\begin{array}{l}\text { Terdapat Perkembangan Signifikan Setelah } \\
\text { Mendapat Pendampingan }\end{array}$ & $100 \%$ & $0 \%$ & $0 \%$ \\
\hline
\end{tabular}

Tabel 1. Hasil Wawancara dari 9 responden

Keterangan Pada Tabel:

SS: Sangat Setuju

KS: Kurang Setuju

TS: Tidak Setuju

\section{Hasil Wawancara Dengan Orang Tua}

1. Mendisiplin "GM" sesuai aturan

Pendisipilinan terhadap "GM" dilakukan oleh orang tua dengan memberitahu kesalahan, menjelaskan berulang-ulang serta dilakukan dengan konsisten orang tua memberikan disiplin namun masih ada hal-hal bagian lain yang belum tegas dalam memberikan disiplin kepada "GM".

2. Melatih "GM" meningkatkan perkembangan

Orang tua membawa "GM" untuk terapi dan sekolah khusus, membawa ke kantor dan ibadah-ibadah agar "GM" bisa bersosialisasi dan berlatih berkomukasi dengan staf dan mahasiswa. Orang tua selalu menanyakan hal-hal yang dilakukan "GM". Orang tua juga memasukkan "GM" ke sekolah formal agar bisa berbaur dan berkomunikasi dengan teman-teman yang sudah lancar bicara.

3. Memberikan memotivasi berupa apresiasi kepada "GM"

Orang tua selalu melatih membacakan dan menunjukkan huruf-huruf di dalam poster yang kami pasang di dinding, membelikan mainan edukatif, memberikan apresiasi jika "GM" berhasil melakukan sesuatu dengan baik, mengedukasi orang dewasa yang berinteraksi dengan "GM", ada kerjasama antara ayah dan ibu untuk mendukung "GM", memberi pujian untuk setiap perilaku yang baik dari "GM". 
4. Orang tua memberi batasanbatasan kepada "GM"

Membatasi waktu penggunaan HP maupun menonton TV, meminta ijin terlebih dulu jika "GM" ingin meminjam atau menggunakan sesuatu milik orang lain, namun orang tua terkadang masih longgar dalam memberikan batasan sehingga anak menjadi menggunakan HP melebihi batas waktu. Orang tua mengingatkan waktu jika hampir habis ketika "GM" bermain sehingga ketika selesai "GM" tidak marah.

\section{Perkembangan "GM" setelah mendapat pendampingan}

"GM" sangat berkembang dengan baik. sejak terapi "GM" mulai bisa menatap mata orang, mulai bisa fokus dalam kegiatan, perlahan mulai belajar meniup lilin, sudah mulai berkurang tantrumnya. Dalam hal bicara, mulai bisa mengucapkan huruf vocal dan mulai mengucapkan katakata. Pendampingan yg lebih awal bisa menolong "GM" untuk bisa berbicara. Perkembangan "GM" sudah sangat baik sekali lewat pendampingan yang orang tua "GM" berikan, "GM" sudah bisa berinteraksi dan berkomunikasi dengan baik dengan lawan bicarannya, "GM" sudah bisa berempati, menurut apa yang dikatakan orang tua "GM", sangat cerdas dan mempunyai IQ yang tinggi. Lebih mudah diarahkan, tenang dan mulai bisa mengkomunikasikan dengan baik apa yang diinginkan, Terutama dalam mengekspresikan emosi cukup berkembang selain itu perkembangan sangat pesat, ketertarikan dengan bahasa asing bisa difasilitasi,
Kemampuannya menyerap bahasa asing sangat cepat.

\section{J. Analisa Hasil Penelitian}

Berdasarkan penyajian hasil penelitian berdasarkan indikator yang ditentukan maka pengasuhan yang dilakukan orang tua "GM" menunjuk pada penggunaan Pola Asuh otoritatif/demokratif yang memotivasi anak-anak agar mandiri disertai dengan batasan-bataasan pengendalian atas tindakan anak. Demikian juga pengasuhan yang diberikan merupakan pengasuhan positif dengan bukti bahwa orang tua membangun kasih sayang, saling menghargai hak serta memberikan lingkungan yang aman bagi "GM" seperti memberi pengertian kepada orang dewasa yang berkomunikasi dengan "GM" untuk menolong membangun komunikasi yang positif. Orang tua dapat menerima "GM" dan berusaha untuk menolong perkembangan "GM" yang optimal. Pengasuhan yang positif sangat dibutuhkan anak yang memiliki kebutuhan khusus sehingga akan menolong perkembangannya dapat maksimal dan upaya penanganan anak berkebutuhan khusus sejak dini sangat memudahkan untuk proses perkembangan tahap selanjutnya.

\section{Kesimpulan}

Salah satu wujud kasih orang tua kepada anak adalah dengan menerapkan pola asuh yang tepat bagi anak. Anak berkebutuhan khusus terus membutuhkan pendampingan dan pengasuhan dari keluarga inti. Penerimaan kondisi awal sangat menentukan untuk penanganan tahap selanjutnya agar anak tidak mengalami tekanan yang semakin berat. Pengasuhan yang diperlukan bagi anak berkebutuhan khusus adalah pengasuhan yang positif karena anak perlu didorong 
kemandirian namun tetap memberikan batasan-batasan yang jelas, dengan demikian orang tua perlu konsisten.

Upaya penanganan yang dilakukan oleh orang tua "GM" dilakukan dengan pola asuh otoritatif berupa mendisiplin sesuai aturan, melatih meningkatkan perkembangan, memberikan motivasi berupa apresiasi, memberi batasan/aturan, membawa "GM" untuk pemerikasaan pendengaran, mengikutkan terapi, memasukkan ke sekolah formal yang umum serta melatih beberapa tips dari pakar ABK di rumah. Dari hal tersebut, perkembangan "GM" terlihat sudah mulai dapat mengucapkan huruf-huruf serta mulai berkata-kata sederhana. Sosio emosional "GM" juga mulai berkembang baik, dapat mengungkapkan pikiran, dapat mulai fokus dan mampu menatap mata orang lain. Sehingga dalam penanganan anak berkebutuhan khusus inisial "GM" kategori gifted, pola asuh otoritatif dianggap tepat untuk mengoptimalkan perkembangan anak.

\section{Referensi}

Aidah, Siti Nur. Tips Menjadi Orang tua Inspirasi Masa Kini. Yogyakarta: KBM Indonesia, 2020.

Anggito, Albi, dan Johan Setiawan. Metodologi Penelitian Kualitatif. Sukabumi: CV Jejak, 2018.

Christie, Phil. Langkah Awal Berinteraksi Dengan Anak Autis. Jakarta: Kompas Gramedia, n.d.

Departemen Pendidikan Nasional. Kamus Besar Bahasa Indonesia. Jakarta: Balai Pustaka, 2002.

Fitriyana, Nur. "Spritualitas Yesus : Mengasihi Sesama Seperti Mengasihi Diri Sendiri.” Jurnal Ilmu Agama: Mengkaji Doktrin, Pemikiran, dan Fenomena Agama
18, no. 2 (December 30, 2017). http://jurnal.radenfatah.ac.id/index.p hp/JIA/article/view/2370.

Ginting, Aliva Humairah Br, dan Ichsan Ichsan. "Pola Asuh Orang tua Pada Anak Cerdas Dan Anak Gifted." El Midad 13, no. 1 (2021): 1-9.

Hannas, Hannas, dan Rinawaty Rinawaty. "Menerapkan Model Penginjilan Pada Masa Kini." KURIOS (Jurnal Teologi dan Pendidikan Agama Kristen) 5, no. 2 (2019): 175-189.

Hardywinoto, dan Tony Setiabudhi. Anak Unggul Berotak Prima. Jakarta, 2003.

Harefa, Ida Destariana, dan Ahmad Tabrani. "Problematika Pendidikan Karakter, Antara Konsep Dan Realita." SHAMAYIM: Jurnal Teologi dan Pendidikan Kristiani 1, no. 2 (May 5, 2021): 148-156. http://sttybmanado.ac.id/ejournal/index.php/shamayim/article/ view/23.

Hartono, Wahyu. Profil Anak Berkebutuhan Khusus (ABK). Jakarta, 2014.

Haryono, Cosmas Gatot. Ragam Metode Penelitian Kualitatif Komunikasi. Sukabumi: CV Jejak, 2020.

Hidayati, Tutik. Pendamping Gizi Pada Balita. Yogyakarta, 2019.

Hurlock, Elizabeth B. Perkembangan Anak. Jakarta, 2005.

Isharjono, Antonius. "Menerapkan Pola Pendidikan Rohani Anak Berkebutuhan Khusus (Attention Deficit or Hyperactivity Disorder)." Jurnal Teruna Bhakti 2, no. 1 (2019): 37-48.

Jaya, Hendra. "Keterampilan Vokasional Bagi Anak Berkebutuhan Khusus Perawatan Dan Perbaikan Alat Elektronika." Fakultas MIPA 
universitas negeri makassar, 2017.

Lidyasari, Aprilia Tina. "Pola Asuh Otoritatif Sebagai Sarana Pembentukan Karakter Anak Dalam Setting Keluarga." Yogyakarta: PGSD FIP UNY (2013).

Lisinus, Rafael, dan Pastiria Sembiring. Pembinaan Anak Berkebutuhan Khusus. Medan: Yayasan Kita Menulis, 2020.

Manurung, Kosma. "Mencermati Arti Penting Penggunaan Bahasa Cinta Anak Dalam Keluarga Kristen Di Era 5.0." EDULEAD: Journal of Christian Education and Leadership 2, no. 1 (June 1, 2021): 53-70. https://stak-pesat.ac.id/ejournal/index.php/edulead/article/vie $\mathrm{w} / 53$.

Masrul. Pandemik COVID-19 Persoalan Dan Refleksi Di Indonesia. Surabaya: Yayasan Kita Menulis, 2020.

Miftakhul Jannah. "Studi Deskripsi : Perekonomian Orang tua Anak Berkebutuhan Khusus Terhadap Pendidikan Anak Berkebutuhan Khusus." SPECIAL: Special and Inclusive Education Journal 1, no. 1 (May 14, 2020): 49-58. http://jurnal.unipasby.ac.id/index.ph $\mathrm{p} / \mathrm{special} /$ article/view/2293.

Ni'matuzahroh, dan Yuni Nurhamida. Individu Berkebutuhan Khusus Dan Pendidikan Inklusif. Malang: UMM, 2016.

Noya, Andris. Pendidikan Papa Mama. Edited by Abdul. Penerbit Adab, 2020.

Purba, Tika Anggreni. “70 Persen Anak Berkebutuhan Khusus Tak Dapat Pendidikan Layak." Bisnis.Com. Jakarta, 2019. https://lifestyle.bisnis.com/read/2019 0326/236/904431/70-persen-anakberkebutuhan-khusus-tak-dapatpendidikan-layak.

Rantung, Djoys Anneke. "Pendidikan Agama Kristen Untuk Keluarga Menurut Pola Asuh Keluarga Ishak Dalam Perjanjian Lama." Jurnal Shanan 3, no. 2 (October 28, 2019): 63-76.

http://ejournal.uki.ac.id/index.php/sh an/article/view/1579.

Rohimah, Siti, Ari Sofia, dan Susanthi Pradini. "Hubungan Pola Asuh Otoritatif Terhadap Kemandirian Anak Usia 5-6 Tahun." Jurnal Pendidikan Anak 5, no. 1 (2019).

Santosa, Santosa. "Urgensi Peran Orang tua Membangun Kepemimpinan Anak Di Era Disrupsi Teknologi Berdasarkan Ulangan 6: 6-9." EDULEAD: Journal of Christian Education and Leadership 2, no. 1 (June 1, 2021): 71-88. https://stakpesat.ac.id/e-

journal/index.php/edulead/article/vie w/61.

Sugiyono. Metode Penelitian Kuantitatif Dan Kualitatif Dan R\&D. Bandung: ALFABETA, 2011.

Telaumbanua, Sozanolo, dan Desi Sianipar. "Patriotisme Kristen." Jurnal Shanan 5, no. 1 (March 30, 2021): 61-78. http://ejournal.uki.ac.id/index.php/sh an/article/view/2734.

Tiel, Julia Maria Van. Pendidikan Anakku Terlambat Bicara. Jakarta: PRENADA, 2011.

Tiel, Julia Maria Van, dan Endang Widyorini. Anak Cerdas Istimewa. Jakarta: Prenadamedia Group, 2014.

Tiel, Julia Maria Van, dan Endang Widyorini. Anak Cerdas Istimewa. Jakarta, 2014. 
Tridonanto, Al, dan Beranda Agency. Pola Asuh Demokratis. Jakarta: Gramedia, 2014.

Wijanarko, Djarot. Intim Orang tua Anak. Jakarta, n.d.

Williams, Chris, dan Barry Wright. How To Live With Autism and Asperger Syindrome. Jakarta: PT Dian Rakyat, 2007.
Wiriadinata, Susan S. Mengasuh Anak Mengasihi Tuhan. Jakarta, 2018. 
